\title{
Monitoring of Vegetative and Floral Characters of Gliricidia sepium
}

\author{
Mayona K. Marak* and Afaq Majid Wani \\ Department of Forest Biology \& Tree Improvement, College of Forestry SHUATS, \\ Allahabad, Naini (U.P.) 211007, India \\ *Corresponding author
}

\section{A B S T R A C T}

\begin{tabular}{|l|}
\hline Ke y w o r d s \\
Leafing, Flowering, \\
Anthesis, Gliricidia \\
sepium
\end{tabular}

Observations were conducted to reveal the vegetative and floral characters in Gliricidia sepium in the School of Forestry and Environment, Sam Higginbottom University of Agriculture, Technology and Science, Allahabad situated at $25028 \mathrm{~N}$ latitude and 810 $55^{\prime} \mathrm{E}$ longitude. Analysis of variance for the characters under observation revealed significant differences for leaf bud swell, leaf bud burst, leafing, senescence, flower bud development stages, anthesis timing, and anther dehiscence. The emergence of new leaves and their development continued up to second week of June. Falling of first and last leaf was observed on last week of December and last week of January respectively. Synchronous flowering of Gliricidia sepium started during first week of March and ends towards first week of April with a peak period of flowering from second week of April to fourth week of April. Anthesis and anther dehiscence took place during morning hours after the onset of Sun. The maximum anthesis and anther dehiscence were observed between 6:30 to 8:30 a.m. and 10:30 to $12: 30$ a.m. respectively

\section{Introduction}

Gliricidia sepium is a medium size, semideciduous leguminous tree belonging to family Fabaceae that typically grows $10 \mathrm{~m}$ to $15 \mathrm{~m}$ in height, with a broad canopy and has a medium crown and may be single or multistemmed. The species is native to Central America and possibly northern South America, its cultivation is now pantropical. It grows best in tropical, seasonally dry climates. The tree thrives in deep, well drained soils although it tolerates shallow soils that have high available calcium levels. The bark of Gliricidia sepium is smooth, and its colour can range from a whitish grey to deep red-brow.
The generic name Gliricidia refers to "mouse killer" in Latin, and the species epithet is named from the Latin saepes meaning hedge.

G.sepium occurs naturally in early and middle successional vegetation types on disturbed sites such as coastal sand dunes, river banks, flood plains and fallow land. It establishes well on steep slopes. It is fast-growing Nitrogen-fixing tree used throughout the tropics for the many environmental services and products it provides. It is widely used to provide crop shade for coffee, cacao and other shade loving crops and other shade loving crops. Today it is used for many other purposes including live fencing, fodder for its 
high nutritional value, firewood, green manure, intercropping, rat poison and as an alternative energy source. This species stand out for its rapid growth, high regeneration capacity, drought resistance and ability to propagate sexually and asexually. It is commonly referred as Gliricidia.

The leaves and flowers are said to be eaten boiled or fried. The flowers attract honey bees (Apis spp.) hence it is important species for honey production (Katende, 1995). It is a good source of nectar. G.sepium leavea are rich in protein and highly digestible, and low in fibre and tannin. Crushed leaves are applied as poultice. It is also used as antihistaminic, antipyretic, expectorant and diuretic. Often used for firewood and charcoal production. Wood is utilized for railway sleepers, farm implements, furniture, house construction and as mother posts in live-fence establishment (Timyan, 1996). Extracts of G.sepium have been shown to have high anti-fungal activity (Stewart, 1996). G.sepium has been planted to reclaim denuded land or land infested with Imperata cylindrical and is also capable of fixing atmospheric nitrogen (MacDicken, 1994; Chirwa et al., 2006).

It is important to study the phenology, as it is prerequisite in plant breeding and obtaining better yields of plants. The ultimate objective of forest tree breeding is to develop fast growing high yielding genetically improved superior trees in order to replace wild natural and low productive plants so as to obtain higher productivity per unit area and time. A clear understanding of phenological behaviour, time of anthesis, anther dehiscence, pollen studies, mode of pollination, seed development etc, is necessary for attempting crosses between genetically different forms which is invariably involved in breeding program, In this research article a successful attempt was made to find out the vegetative and floral characters of Gliricidia sepium.

\section{Materials and Methods}

The present observations were conducted in the School of Forestry and Environment, Sam Higginbottom University of Agriculture, Technology and Science, Allahabad, U.P. India, situated at $25028^{\prime} \mathrm{N}$ latitude and 810 $55^{\prime} \mathrm{E}$ longitude. The area is located at an altitude of $98 \mathrm{~m}$ amsl and enjoys sub-tropical climate with an average annual rainfall of $1100 \mathrm{~mm}$. The investigation was carried out for vegetative and floral characters of Gliricidia sepium. A specific number has been given to all 5 selected sample trees for observation. Ten branches from each tree, totaling fifty branches in all were selected in all directions and tagged with a transparency tag. The data were recorded on initiation and completion of phenological events of vegetative character and reproductive character. In the vegetative character leaf bud swell, leaf bud burst, leafing and senescence were studied. In the reproductive character flower bud swell, flower bud burst, flowering, anthesis and seed dispersal were recorded by making regular visits to the observation sites. The data was subjected to statistical analysis.

\section{Results and Discussion}

Analysis of variance revealed significant differences for leaf bud swell, leaf bud burst, leafing, senescence, flower bud development stages, anthesis timing, and anther dehiscence. A close morphological observations of leaves of Gliricidia sepium showed that the buds appeared in axile. Buds are light green in colour. The average length was recorded 0.1 $\mathrm{cm}$. The Leaf bud swell started in the midJanuary and leaf bud burst in the last week of January. Leaf renewal initiation started in the first week of February.

The data depicted maximum number of days taken for leaf bud swell and leaf bud burst, respectively were 60.8 days $\left(\mathrm{T}_{5}\right)$ and 33 days 
$\left(\mathrm{T}_{5}\right)$ presented in Table 1. For leafing maximum number of days taken were 104.5 $\left(\mathrm{T}_{5}\right)$ shown in Table 1 . The emergence of new leaves and their development continued upto second week of June. Data revealed that leaf fall in Gliricidia sepium took maximum of 45.6 days. The first leaf fall started in last week of December (winter season) and continued till last week of January. At all times during the study there was atleast some leaf buds producing new leaves. Similar findings were reported in phenological studies (Kikim and Yadava, 2001) in subtropical forests of Manipur, India.

Gliricidia sepium is a medium size $10-15 \mathrm{~m}$ tall semi-deciduous leguminous tree with spreading branches having alternate and pinnate leaf arrangement. G. sepium flowers are grouped in dense racemes with the short peduncle. The calyx-tube is urn-shaped and the calyx is pinkish purple-coloured. The corolla is composed of 5 pink-coloured, glabrous and clawed petals. Synchronous flowering started during first week of March and ends towards first week of April. Full blooming period was observed from the second week of March to first week of April.

Peak period of flowering was noticed during second week of March to fourth week of March with significant variation in the flowering period from plant to plant. Data revealed that the maximum number of days was 35.6 days $\left(\mathrm{T}_{1}\right)$ for flower bud swell and 45.8 days $\left(T_{5}\right)$ for flower bud burst. It was observed that maximum total number of days for flowering was 42.1 days $\left(\mathrm{T}_{3}\right)$ [Table 2; Fig. $\mathrm{A}-\mathrm{H}]$.

Table.1 Total no. of days taken for various vegetative phytophases in Gliricidia sepium

\begin{tabular}{|c|c|c|c|c|}
\hline Trees no. & Leaf bud swell & Leaf bud burst & Leafing & Leaf fall \\
\hline $\mathrm{T}_{1}$ & 56.9 & 32.4 & 90.5 & 43.5 \\
\hline $\mathrm{T}_{2}$ & 58.2 & 32.8 & 95.9 & 44.8 \\
\hline $\mathrm{T}_{3}$ & 60.4 & 29.1 & 100.5 & 45.6 \\
\hline $\mathrm{T}_{4}$ & 57.1 & 31.9 & 102.3 & 44.8 \\
\hline $\mathrm{T}_{5}$ & 60.8 & 33 & 104.5 & 44.8 \\
\hline Mean & 58.68 & 31.84 & 98.74 & 44.7 \\
\hline F-test & $\mathrm{S}$ & $\mathrm{S}$ & $\mathrm{S}$ & $\mathrm{S}$ \\
\hline C.D at 5\% & 2.906 & 2.787 & 1.996 & 1.306 \\
\hline SE (d) & 1.427 & 1.368 & 0.980 & 0.641 \\
\hline
\end{tabular}

Table.2 Total number of days taken for various reproductive phytophases in Gliricidia sepium

\begin{tabular}{|c|c|c|c|c|c|}
\hline Trees No & Flower bud swell & Flower bud burst & Flowering & Fruiting & Seed dispersal \\
\hline $\mathrm{T}_{1}$ & 35.6 & 40.6 & 40.4 & 42.7 & 35.5 \\
\hline $\mathrm{T}_{2}$ & 31.6 & 42.1 & 41.0 & 44.1 & 34.7 \\
\hline $\mathrm{T}_{3}$ & 31.9 & 42.2 & 42.1 & 45.0 & 36.3 \\
\hline $\mathrm{T}_{4}$ & 32.8 & 44.5 & 41.8 & 46.5 & 37.4 \\
\hline $\mathrm{T}_{5}$ & 34.0 & 45.8 & 39.7 & 47.0 & 38.4 \\
\hline Mean & 33.18 & 43.04 & 41 & 45.06 & 36.46 \\
\hline F-test & $\mathrm{S}$ & $\mathrm{S}$ & $\mathrm{S}$ & $\mathrm{S}$ & $\mathrm{S}$ \\
\hline C.D at 5\% & 1.360 & 1.969 & 1.000 & 1.489 & 1.436 \\
\hline SE(d) & 0.668 & 0.967 & 0.491 & 0.731 & 0.705 \\
\hline
\end{tabular}


Int.J.Curr.Microbiol.App.Sci (2018) 7(9): 1576-1582

Table.3 Mean value of different stages of reproductive bud development to anthesis in Gliricidia sepium

\begin{tabular}{|c|c|c|c|c|c|c|c|c|c|c|c|c|c|}
\hline \multirow{2}{*}{\multicolumn{2}{|c|}{ Plus tree }} & \multicolumn{10}{|c|}{ No. of days taken during different bud development stages } & \multirow{2}{*}{$\begin{array}{l}\text { Anthesis } \\
\text { time } \\
\text { XI-XII }\end{array}$} & \multirow{2}{*}{$\begin{array}{c}\text { Total } \\
\text { no. of } \\
\text { days }\end{array}$} \\
\hline & & I-II & $\begin{array}{l}\text { II- } \\
\text { III }\end{array}$ & $\begin{array}{l}\text { III- } \\
\text { IV }\end{array}$ & $\begin{array}{l}\text { IV- } \\
\text { V }\end{array}$ & $\begin{array}{l}\text { V- } \\
\text { VI }\end{array}$ & $\begin{array}{l}\text { VI- } \\
\text { VII }\end{array}$ & $\begin{array}{l}\text { VII- } \\
\text { VIII }\end{array}$ & $\begin{array}{l}\text { VIII- } \\
\text { IX }\end{array}$ & $\begin{array}{l}\text { IX- } \\
\text { X }\end{array}$ & $\begin{array}{l}\text { X- } \\
\text { XI }\end{array}$ & & \\
\hline \multirow{5}{*}{$\begin{array}{l}\text { D } \\
\text { A } \\
\text { Y } \\
\text { S }\end{array}$} & $\mathrm{T}_{1}$ & 2.0 & 2.5 & 3.1 & 3.2 & 4.4 & 4.6 & 5.2 & 3.3 & 2.4 & 1.8 & 1.1 & 33.6 \\
\hline & $T_{2}$ & 2.3 & 2.8 & 3.0 & 3.3 & 4.1 & 4.3 & 5.0 & 3.0 & 2.6 & 2.0 & 1.6 & 34.0 \\
\hline & $\mathrm{T}_{3}$ & 2.4 & 2.4 & 2.8 & 3.5 & 3.8 & 4.4 & 5.4 & 3.2 & 2.2 & 2.3 & 1.3 & 33.7 \\
\hline & $\mathrm{T}_{4}$ & 2.1 & 2.6 & 3.2 & 3.1 & 4.2 & 4.2 & 5.0 & 3.1 & 2.1 & 2.1 & 1.8 & 33.5 \\
\hline & $\mathrm{T}_{5}$ & 2.0 & 2.6 & 2.7 & 3.2 & 3.8 & 4.3 & 5.3 & 2.8 & 2.4 & 2.4 & 1.4 & 32.9 \\
\hline \multicolumn{2}{|c|}{ Mean } & 2.16 & 2.58 & 2.96 & 3.26 & 4.06 & 4.36 & 5.18 & 3.08 & 2.34 & 2.12 & 1.44 & 33.54 \\
\hline
\end{tabular}

Table.4 Average value for Anthesis timing in Gliricidia sepium

\begin{tabular}{|c|c|c|c|c|c|c|}
\hline \multicolumn{7}{|c|}{ ANTHESIS TIMING } \\
\hline TREE NO. & $6: 30-8: 30$ & $8: 30-10: 30$ & $10: 30-$ & $12: 30-$ & $14: 30-$ & $16: 30-$ \\
& & & $12: 30$ & $14: 30$ & $16: 30$ & $18: 30$ \\
\hline $\mathrm{T}_{1}$ & 1.9 & 1.5 & 1.2 & 0.9 & 0.6 & 0.5 \\
\hline $\mathrm{T}_{2}$ & 1.8 & 1.1 & 0.9 & 0.6 & 0.5 & 0.4 \\
\hline $\mathrm{T}_{3}$ & 3.6 & 1.2 & 1 & 0.7 & 0.6 & 0.5 \\
\hline $\mathrm{T}_{4}$ & 4.1 & 1.5 & 0.7 & 0.4 & 0.4 & 0.3 \\
\hline $\mathrm{T}_{5}$ & 3.2 & 0.3 & 1.2 & 0.8 & 0.7 & 0.2 \\
\hline $\mathrm{MEAN}$ & 2.92 & 1.12 & 1 & 0.68 & 0.56 & 0.38 \\
\hline $\mathrm{SD} \pm$ & 1.03 & 0.49 & 0.21 & 0.19 & 0.11 & 0.13 \\
\hline
\end{tabular}

Table.5 Average value for Anther dehiscence in Gliricidia sepium

\begin{tabular}{|c|c|c|c|c|c|c|}
\hline \multicolumn{7}{|c|}{ ANTHESIS DEHISCENCE } \\
\hline $\begin{array}{c}\text { TREE } \\
\text { NO. }\end{array}$ & $\begin{array}{l}6: 30- \\
8: 30\end{array}$ & $\begin{array}{l}8: 30- \\
10: 30\end{array}$ & $\begin{array}{l}10: 30- \\
12: 30\end{array}$ & $\begin{array}{c}12: 30- \\
14: 30\end{array}$ & $\begin{array}{c}14: 30- \\
16: 30\end{array}$ & $\begin{array}{c}16: 30- \\
18: 30\end{array}$ \\
\hline $\mathrm{T}_{1}$ & 0.6 & 1.2 & 1.9 & 1 & 0.5 & 0.3 \\
\hline $\mathbf{T}_{2}$ & 0.4 & 1.3 & 2.1 & 1.2 & 0.3 & 0 \\
\hline $\mathbf{T}_{\mathbf{3}}$ & 0.8 & 2 & 2.2 & 0.7 & 0.4 & 0.1 \\
\hline$T_{4}$ & 0.3 & 0.8 & 1.8 & 0.6 & 0.2 & 0.1 \\
\hline $\mathbf{T}_{5}$ & 0.2 & 2 & 1.4 & 0.4 & 1.2 & 0.1 \\
\hline MEAN & 0.46 & 1.46 & 1.88 & 0.78 & 0.52 & 0.12 \\
\hline SD \pm & 0.24 & 0.53 & 0.31 & 0.32 & 0.40 & 0.11 \\
\hline
\end{tabular}


Fig. A Leaf bud swell in G.sepium, Fig. B Leaf bud enlargement in Gliricidia sepium., Fig. C Leaf bud burst in G.sepium., Fig. D Flower bud burst in G.sepium., Fig. E Flowering in G.sepium., Fig. F Fruiting in G.sepium., Fig. G Developed pod of G.sepium., Fig. H Seeds of G.sepium

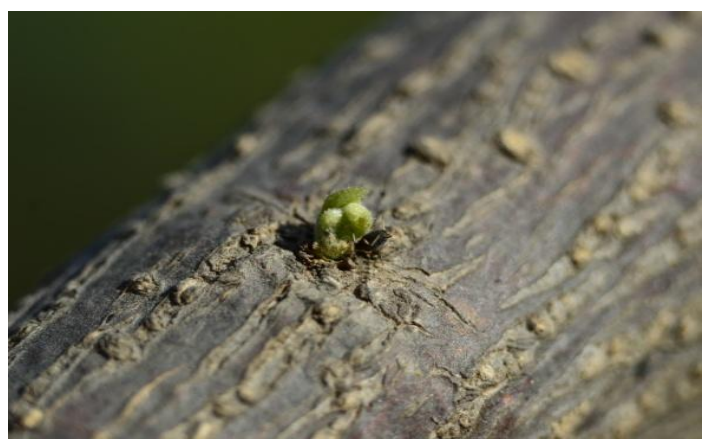

A

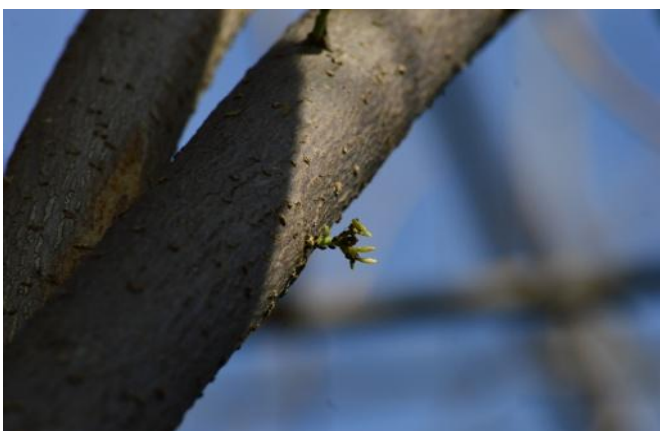

C

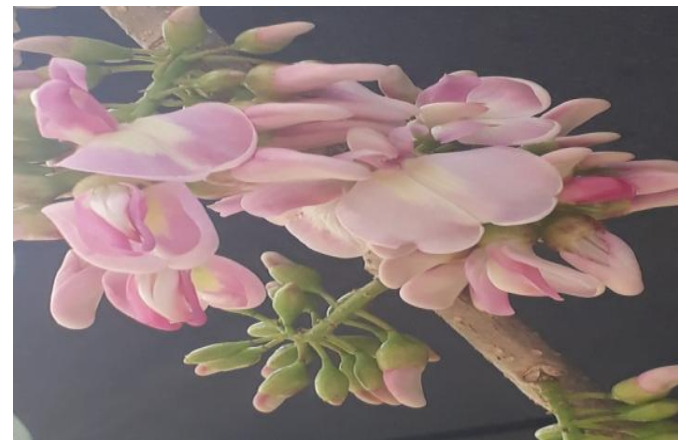

$\mathbf{E}$

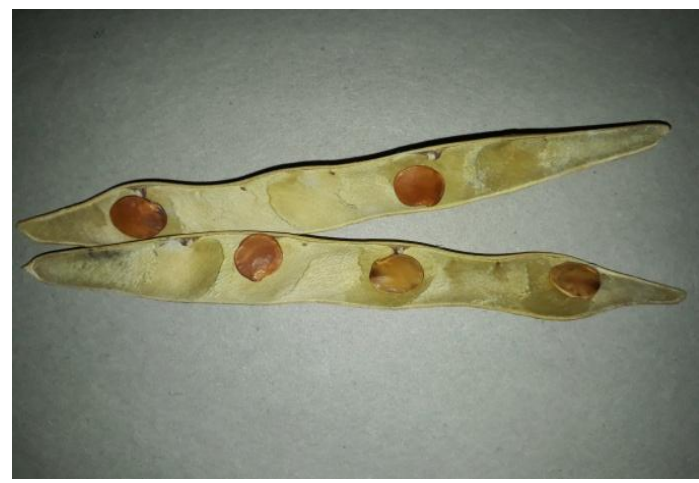

G
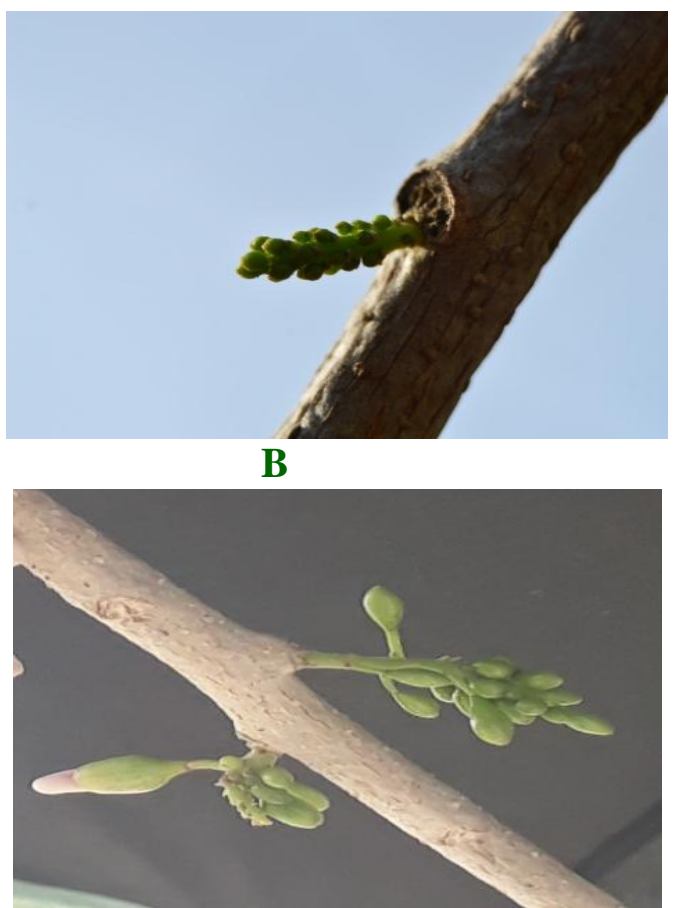

D

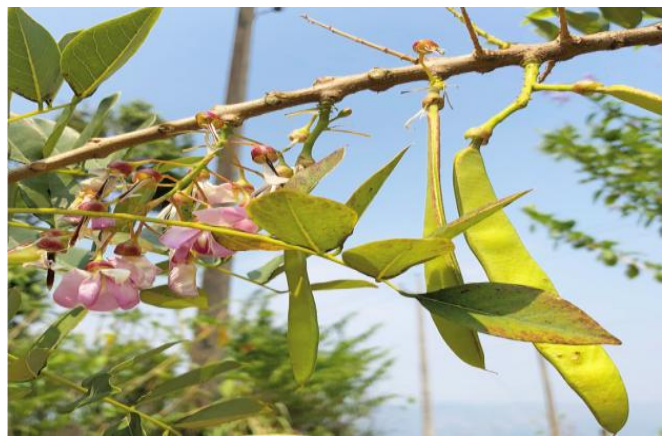

F

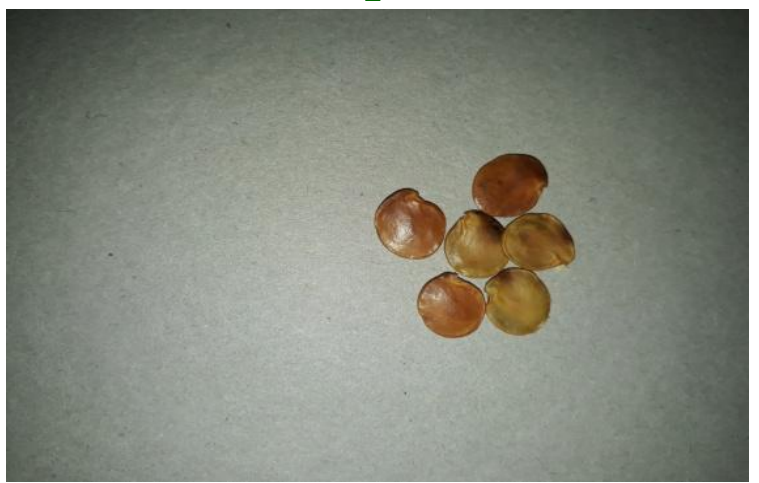

H 
A flower showed twelve district stages of flower bud development and took 32.9 to 34.0 ( $\mathrm{T}_{5}$ to $\mathrm{T}_{2}$ ) days to anthesis (Table 3). (Nath and Randhawa, 1959; Josan et al., 1979; Sharma, 2001) also reported similar bearing habit in different pomegranate cultivars and parallel results were obtained by (Pant et al., 1997) in Grewia optiva (Wani et. al., 2008) in B. variegata

In the present study, the peak period of mature fruits occurs in the month of April. The formation of fruit set was observed 3-4 days after flowering. In the process of preparation for fruit set development the flowers started to wilt and dry and turned pale with change in colour from bright pink to lilac colour that is tinged with white to darker shades. Ripening of fruits initiated with the increase in temperature from March to April. Table 2 revealed that maximum number of days for fruiting was 47 days $\left(\mathrm{T}_{5}\right)$ and for seed dispersal was 38.4 days $\left(\mathrm{T}_{5}\right)$. Visual observation showed that fruit is a pod usually $10-12 \mathrm{~cm}$ long and $1.5-1.8 \mathrm{~cm}$ broad. The pods contained about 5-6 round seeds and are brown in colour. Fruit turned brown on maturity. The seeds of Gliricidia sepium measured about $1 \mathrm{~cm}$ in diameter.

Flower opening was observed from the appearance of balloon shaped flower bud. The maximum anthesis was observed between 6:30 to $8: 30$ a.m. at all the five different trees (Table 4). Almost similar timings were observed in different tree species by various workers viz., (Balalia and Chauhan, 1994) in Delonix regia (06:00 to 07:00 a.m.), in Moringa oliefera species Bhattacharya (2004) reported flower anthesis between $06.00 \mathrm{~h}$. to $12.00 \mathrm{~h}$. and pollen anthesis between $07.00 \mathrm{~h}$ - 13.00 h (Wani and Chauhan 2008) in B. variegata. Maximum anther dehiscence was observed between 10:30 a.m to 12:30 p.m. in all the five trees (Table 5). (Sareen and Vasisht, 1983) recorded anther dehiscence in
Delonix regia by longitudinal slits between 10:00 to 11:00 a.m. and 03:30 to 04:00 p.m.

From the present observations, it is concluded from the study of vegetative characters that the emergence of new leaves and their development continued up to second week of June. Falling of first and last leaf was observed on last week of December and last week of February respectively. Synchronous flowering of Gliricidia sepium started during first week of March and ends towards first week of April with a peak period of flowering from second week of March to fourth week of March. Flower bud development took 32.9 to 34.0 days to anthesis. Anthesis and anther dehiscence took place during morning hours after the onset of Sun. The maximum anthesis and anther dehiscence were observed between 6:30 to $8: 30$ a.m. and 10:30 a.m to $12: 30$ p.m respectively.

\section{References}

Balalia R, Chauhan SVS (1994). Phenology and reproductive biology of some leguminous trees. J Tree. Sci.; 13(2):121-123.

Bhattacharya A. and Mandal S., (2004). Pollination, pollen germination and stigma receptivity in Moringa oleifera Lamk. Journal Grana, 43(1): 48-56.

Chirwa P.W., Black C.R., Ong C.K. and Maghembe J., (2006). Nitrogen dynamics in cropping systems in southern Malawi containing Gliricidia sepium, pigeonpea and maize. Agroforestry Systems 67:93-106

Katende A.B., (1995). Useful trees and shrubs for Uganda. Identification, propagation and management for agricultural and pastoral communities. Regional soil conservation unit (RSCU), Swedish International Development Authority (SIDA). 
Kimkim A. And Yadava P.S., (2001). Phenology of tree species in subtropical forests of Manipur in north eastern India. Tropical Ecology (International Society for Tropical Ecology), 42(2): 269-276.

MacDicken G.K., (1994). Selection and management of nitrogen fixing trees. Winrock International, and Bangkok : FAO.

Nath N, Randhawa GS. Studies on floral biology in the pomegranate (Punica granatum L.). Ind. J Hort. 1959; 16:121-135.

Pant, K.S., Sehgal R.N. and Sharma S.S., (1997). Floral biology and breeding system in Grewia optiva. Indian Journal of Forestry. 20 (4):309-313.

Sareen TS, Vasisht S. Breeding systems of Delorux regia Raf. Improvement of Forest Biomass (Khosla, P.K. ed.), Pragati Press, Delhi, 1983, 33-40.

Sharma N. Studies on floral biology, pollination and fruit characteristics of some pomegranate (Punica granatum
L.) cultivars. M.Sc. Thesis, Dr. Y. S Parmar University of Horticulture and Forestry, Solar (H.P.). 2001, 54.

Stewart JL, Allison GE, Simons AJ, 1996. Gliricidia sepium. Genetic resources for farmers. Tropical Forestry Paper 33. Oxford, UK: Oxford Forestry Institute.

Stewart JL, Allison GE, Simons AJ, 1996. Gliricidia sepium: genetic resources for farmers. Tropical Forestry Papers, No. 33:vi + 125 pp.; many ref.

Timyan J., (1996). Bwa Yo: important tree of Haiti. South-East Consortium for International Development. Washington D.C.

Wani, A.M. and Chauhan. K.C. 2008. Floral Biology and Stigma Receptivity in Bauhinia variegata Linn. Indian Forester. 134: (2).233-240.

Wani, A.M. Raj, A.J and Chauhan. K.C. 2008. Phenological observation of Bauhinia variegata Linn. - a woody angiosperm. My Forest. 44 (2): 111114.

\section{How to cite this article:}

Mayona K. Marak and Afaq Majid Wani. 2018. Monitoring of Vegetative and Floral Characters of Gliricidia sepium. Int.J.Curr.Microbiol.App.Sci. 7(09): 1576-1582. doi: https://doi.org/10.20546/ijcmas.2018.709.189 